\title{
PADA GELAHANG MARRIAGE: A LEGAL PLURALISM PERSPECTIVE
}

\author{
I Putu Sastra Wibawa*, I Putu Gelgel, and I Putu Sarjana \\ Faculty of Religious and Cultural Science, Universitas Hindu Indonesia \\ *<sastra@unhi.ac.id>
}

\begin{abstract}
Presently, pada gelahang marriages are still controversial within Balinese society in terms of their implementation and the implications. A certain percentage of Balinese approve of pada gelahang marriages, while a certain percentage of people disagree for various reasons. These pros and cons are not tolerated. In fact, the phenomenon of pada gelahang marriages is often confounding to the Hindu community in Bali. Hence, solutions are required. While pada gelahang marriages can be found in many districts and regions in Bali, however, many doubts and problems still arise in their philosophical and juridical foundations. Therefore, research on pada gelahang marriages from the perspective of legal pluralism needs to be done. This research is a qualitative research with a legal sociology approach. Primary data is derived from field data from observations and from the results of interviews of related parties, while secondary data is obtained from literature books using the theory of legal pluralism as a guiding theory in the discussion of research. The results of the study indicate that the pada gelahang marriage has a philosophical foundation, juridical foundation and sociological basis for the creation of values of justice, legal certainty and the benefit of law in the framework of legal pluralism that provides a way to meet Hindu religious law, traditional village customary law and state law to set pada gelahang marriages.
\end{abstract}

Keywords: Pada gelahang, Marriage, Legal Pluralism

\section{Introduction}

Presently the Balinese customary law recognizes only two forms of marriages: 1) the marriage that commonly takes place, and 2) the nyentana marriage. Commonly, the bride is invited to move into the house of the bridegroom. While in a nyentana marriage the girl does not leave her home and join her husband, but her 
husband moves in with his wife. This kind of marriage is usually done if the family does not have a male heir (Windia, 2013). The marriage system is closely related to patrilineal Hindu societies in Bali (male or purusa lineage). Under a patrilineal system, the family genealogy is drawn to the father's lineage. In such a family system, the absence of male heirs is often a serious problem with the marriage system being implemented.

Before the family planning program was implemented in the province of Bali, usually for a Balinese couple, it was common to have four children(named according to the respective order of the birth: Wayan, Made, Nyoman and Ketut). However, after the the successful implementation in Bali Province, there was a change of view in Balinese society. Since then, having two children is considered sufficient; whether they be male or female, both are seen as having equal standing. Until today most married couples in Bali now only have two children. In fact, it is not uncommon for couples to have only one child. Often a serious problem occurs when it comes to the implementation in relation to the traditional Balinese marriage system.

When there is only one daughter within a family, the way out for this family lies in the decision of the soon-to-be-married child to choose the form of marriage that ensures the sustainability of the family. There will be a problem for the woman if her prospective husband is the only male heir of the family. Usually his side of the family are not willing to let him move into the family of his future wife, due to the need of his family to continue their lineage. In such a situation what can be done by families who face such problems? When such problems arise, the alternative chosen by the Hindu community in the Province of Bali is to have a pada gelahang marriage, which is the marriage that sets the status of purusa to the two brides (windia, 2013). Related to the marriage system implemented.

Nowadays the forms of marriage in the context of pada gelahang still occur in the community, both about the implementation and implications of pada gelahang marriage on the one hand there is the consent to the marriage on the other hand pada gelahang marriage no one disagrees.

Who agreed to state that marriage is a marriage that took place pada gelahang is in accordance with the teachings of Hinduism and customary law Bali (Sudantra, 2011), on the other hand those who disagree argue that pada gelahang marriages are incompatible with the teachings of Hindu Religious and customary law of Bali. Pada gelahang marriage is a marriage that is contrary to the basic principle and teachings of Hinduism because mating between the purusa to purusa (Artadipa, 2018). 
Article 2 Paragraph (1) Law No. 1 of 1974 concerning marriage states that marriage is legal if carried out according to the laws of each religion. Hindus must use Hindu law in their marriage. This means that the legitimacy of marriage for Hindus rests on that it does not conflict with Hindu law.

The pros and cons of this course can not be allowed, because the phenomenon of pada gelahang marriage is confusing to the Hindu community, therefore it is necessary to find solutions. Sociologically even when pada gelahang marriages are carried out, many grey areas still remain in the philosophical and juridical area. Therefore, research on marriage pada gelahang from the perspective of legal pluralism needs to be done.

\section{Research Problems and Methods}

This article is based on a qualitative research using a legal sociology approach. Primary data is derived from field data taken from observations and the results of related party interviews, while secondary data is obtained from literature books. This study raises concerns about whether pada gelahang marriages are in accordance with the principle of legal pluralism both in terms of the rules and their implementation. Legal pluralism theory is used to analyze the main problems, in which state laws, religious law and customary law have good synergy in achieving justice, legal certainty and the benefit of law for the community.

\section{Discussions}

\section{The foundation of pada gelahang marriages}

Marriages formed in the midst of wars in Bali is generally accepted by the community as a solution to the problem of marriages in Bali. As a solution, of course, pada gelahang marriages in part have a strong foundation so that they can be classified as one of the solutions. There are three factors that form the foundations in the pada gelahang marriage, mainly, the philosophical foundation, juridical foundation and the sociological basis of pada gelahang marriage which is then clarified with a description of the purpose of the marriage in the slat as follows.

The philosophical foundation of pada gelahang marriage carries justifications for it being one of the solutions to marital problems in Bali. The philosophical foundation contains the ideal values of justice in the field of marital law. The enthusiasm for achieving a win-win solution between men and women of mutual trust and both parties making an agreement to hold a pada gelahang marriage as a symbol of justice in the field of marital law in Bali.

Departing from the common factorial causes of pada gelahang marriages in Bali (Wayan P Windia, et.al) there are at least two factors leading to a pada gelahang marriage, 
among others, 1) the concerns for the legacy left by their parents and ancestors, both tangible responsibilities or liabilities (swadharma) and rights (swadikara), and 2) the agreement between the bride and groom and their respective families to enter into a pada gelahang marriage. Because of the desire to be able to carry out obligations (swadharma) and rights (swadikara) as a child in Bali, the philosophical justification for a pada gelahang marriage in Bali are fulfilled.

In the life of the state, the basic values of Pancasila should appear in applicable legislation, in other words, legislation must be inspired by the values of Pancasila, and not be in conflict with them. In relation to marriages, there is a balance between rights and obligations, as well as their collective agreement by the values of justice derived from a democratic consensus. Thus it can be argued that the pada gelahang marriage has the national values of Pancasila embedded in its philosophical foundation.

Other concepts that add to the philosophical foundations include Dewa Sesana, Pitra Sesana, Putra Sesana and Susila Sesana. Ultimately everything rests on the bride and groom. Dewa sasana is an obligation to worship ancestors, family origins both respect from both men and women. Pitra Sasana is an obligation before parents, both from the bride and groom. Putra Sasana, the relationship between parents and children, even though they are married, the relationship between children and parents is inseparable. Susila sasana is a relationship between children and parents related to everyday social life.

Other philosophical foundations are led by Sulinggih/Pandita and/or the Pemangku (holder), so it can be said that marriages in the area do not conflict with Hindu or Vedic law on the grounds that people who know the Vedas are regarded as saints who want to be witnesses and lead the pada gelahang marriages. Thus, with the pada gelahang marriage being led by spiritual leaders, philosophically speaking, the marriage can be further considered as abiding to Hindu law. In reference to a source of the Hindu law, Sila (Thoughts, Words and Deeds saint/Sulinggih), the pada gelahang marriage should be led by people who are sanctified.

Judicially, pada gelahang marriages have strong grounds in their application in Bali, in the national law, Hindu law, as well as customary law (awig awig). Pada gelahang marriages are based on national law set forth in Act No. 1 of 1974 on the principles of marriage and Government Regulation No. 9 of 1975 on the Implementation of the Principles of marriage because the spirit of pada gelahang is in the collective agreement and the legal basis would not be released from the principle pacta sersuvanda, which means that the agreement becomes the law of 
both parties who make the agreement contained in Article 1338 of the Civil Code. While related to the legal conditions, the agreement is regulated in article 1320 of the Civil Code. For the agreement to be valid, 4 conditions are necessary:

1. Agree to those who are tied together

2. The ability to make an alliance.

3. Certainty.

4. A lawful reason.

The first and second conditions are called subjective requirements, as regards the subjects making the agreement. The third and fourth conditions are called objective conditions because of the object in the agreement. The First Condition "Agree to those who are tied together" means the parties to the agreement shall agree on the subject matter or the subject matter agreed upon, where the agreement shall be reached without any coercion, fraud or omission (Article 1321 Civil Code). The Second Condition, "the ability to make an alliance" Article 1330 KUHP has already regulated any parties that may or may be considered to make an agreement. Based on the above mentioned case, with the agreement of both parties in accordance with the rules mentioned above, then the law of pada gelahang marriage in which there is a mutual agreement has been valid before the law and has binding legal force.

There is also a court ruling that reinforces the existence of a pada gelahang marriage in Bali, the Court of Appeal of the Supreme Court of the Republic of Indonesia No. 1331 K/Pdt12010 examining the civil case in the cassation rate has decided the following in the matter: Dra. Ni Made Lely Nawaksari, Ni Nyoman Sri Rahayu Madya and Governor of the Bali Provincial Government cq Regent of Karangasem Regency cq Head of Civil Registration and Family Planning Citizenship Planning Karangasem Regency First Appellate Cases of Defendants and Defendants/ Comparisons and Compared against Ni Made Sudiasih, Amd. Terminator Kasasi first Plaintiffs/Planned in the Cassation decision, one of them stated that "marriage with the same status of Purusa is lawful". This means that the status of Purusa equals that the men and women become descendants of their respective families, this form of marriage is referred to as a pada gelahang marriage.

Furthermore, legally recognized pada gelahang marriages after a meeting held in PHDI Bali Province December 29, 2008, contains some conclusions recommended by PHDI Bali province with the Supreme PHDI the Assembly Decree No. 13/Kep/P.A.Parisada/ $\mathrm{X} / 2009$.

The conclusions are specifically about pada gelahang marriages made by speaker Prof. Dr. I Made Titib, Ph.D. and Dr. I Wayan P. Windia, S.H. M.Si, as follows: 
First, negen-dadua marriage or pada gelahang marriage is a marriage held in accordance to the teachings of Hinduism and Balinese customary law which does not include ordinary marriage (also known as "marrying out") and also does not include the marriage of nyentana (also known as kaceburin), but the husband and wife remain as the status of head in their respective homes. Hence, in this form of marriage both partners must carry out two responsibilities and obligations (swadharma) simultaneously, namely continuing the family responsibilities of the bride as well as continuing the family responsibilities of the groom. According to Hinduism it can be justified according to the source of Hindu law called "dharma mulam", namely Sruti is Vedic or Revelation, Smerti is the interpretation of revelations from saints, Sila is the behavior of sadu (good sentient beings), Acara are good habits which are believed to be true by society, and Atmanastusti are good behaviors that give satisfaction or happiness to oneself. In the Manawa Dharmasastra or Weda Smrti book IX about Atha Nawanodhayayah, sloka 132, 133, 134,135 and 136 have regulated the appointment of women to the status of purusa.

Second, marriages ("negen dadua") in every district or region in the province of Bali carry a different name. From research conducted by the research team of the Association of Lecturers of Customary Law (Pershada) Bali, 2008, several names that are synonymous to pada gelahang marriage were found, in particular, mepanak bareng marriage, nadua umah marriage, mekaro lemah marriage, negen or bear father, magelar warang marriage, parental marriage, nyentana marriage (nyeburin) with the agreement without the ceremony (mapamit).

Third, the according to research results throughout the districts in Bali, 28 couples were reported to have carried out negen dadua marriages. This number may well be higher because many people may not wish their "negen dadua" marriage to be made known.

Fourth, in paruman walaka it has been discussed and concluded that since many people in Bali who have gone through marriage negen dadua or with various other terms and therefore already hold a foundation of Hinduism, therefore negen dadua according to Hindu law can be justified and not in conflict with the teachings of Hinduism.

Fifth, the negen dadua marriage is seen as a positive cultural shift. Negen dadua marriages have led to the right of inheritance for women. Thus, it is a tribute to human rights law, especially for female heirs.

Sixth, as a condition for its validity, the negen dadua marriage must go through some formal rites according to Balinese Hinduism customs, namely, (a) the pabiyakaonan ceremony has been 
held (b) to not carry out the mapamit ceremony, (c) the marriage alliance has been agreed by the bride, groom and their respective parents.

Seventh, the impact on the holding of the negen dadua marriage is tied to the purusa status. Thus the bride is the successor of the bloodline in her parents' house. Likewise, the groom still serves as purusa or successor of the bloodline in his parents' house.

Eighth, children born from negen dadua marriages "dadua negen" before him with purusa status, which then raises obligations (swadarma) and rights (swadikara) and/or relationships with the local community (pasidikaran) determined according to agreement. Furthermore, based on the Decision of the Supreme Court of Parisada Hindu Dharma Indonesia Number: 13/ Kep/PA Parisada/X/2009 concerning Recommendations on the basis of considerations, among others: that in connection with the development and dynamics of changes that occur in the lives of Hindus with various new and old problems need to get attention and resolution by Hindus, and that the problem concerns the fields of: Empowering the people in the economic field, empowering the people in the fields of education, health, and gender equality.

As well as paying attention to the proposals and suggestions of participants in the Plenary Session III of the Great Companion of the Parisada
Hindu Dharma Indonesia on October 19, 2009 in the recommendation of letter (j), it provides recommendations on the negen dadua marriage.

By law, pada gelahang marriages must be made in accordance with customary laws (awig-awig) in each district or indigenous village. Vise versa, these marriages are recognized based on the village customary laws, as long as the village condone holding pada gelahang marriages. For example, as can be seen in the Gadungan Traditional Village, Selemadeg Timur Sub-district, Tabanan Regency, in chapter 48 verse 2 mentioned that "Pawiwahan madua umah kadadosang, sakewanten mangda tan ngametuang wicara, patut kakaryanang ilikita sane pastika (nganggen materai) sane kasaksinin antuk kaluarga saking purusa lan pradhana miwah prajuru desa pakraman" translation is marriage "madua umah" (pada gelahang) is allowed, but not to cause problems later in life, must be made using the letters with a definitive stamp witnessed by the family of the man and woman and is attended by the indigenous village committee. With the support of merely one indigenous village, pada gelahang marriages can be presented to the jurisdiction as possessing legal power backed by the customary laws of the village.

In addition there is also the Main Assembly Decision Pakraman Bali (MUDP) Bali No. 01/Kep/PSM-3/MDP 
Bali/X/2010 dated October 15, 2010 regarding the results of the third General Assembly of the the Main Assembly Pakraman Bali. It was stated that at one point of the decision, pada gelahang marriages developed because of the willingness of the marriage couples and their parents in Bali to proceed with such marriages. In the cultural context of family expectations to produce offspring and continue the lineage, there were couples and families who hence chose the pada gelahang marriage from among other forms of marriages, namely, the common marriage and nyentana/nyeburin marriage.

With regard to the sociological aspect, the ada gelahang marriages in 2012 shows approximately 49 couples in each regency and city in Bali had pada gelahang marriage. This shows that sociologically, by that period, pada gelahang had been accepted by the society in general. Regardless of the practice, various issues still arise.

\section{Pada gelahang marriages in legal pluralism perspective}

Pada gelahang associated with marriage in the study of legal pluralism, borrow ideas from the Menski triangle (Sukirno, 2014) which divides three points of view: the viewpoint of the state; community; as well as the moral, ethical and religious pluralism within the framework of the law. In the view of the state, recognition of indigenous rights in the field of marriage laws is based on the terminology "to protect".
In addition the state must attend to its responsibility to respect, fulfill and protect the rights of citizens who choose pada gelahang marriages.

From the point of view of society, state recognition of marriage ivy communities who choose to fight must also be protected by social realities. The rights that are well received and supported by the indigenous locals as the unitary customary law that citizens who choose pada gelahang marriages must receive an offer to achieve this (right). This is in accordance with the opinion of John Rawls, who stated that principle of justice is the result of agreement and fair bargain. Due to their position, everyone's relationship becomes symmetrical, early situations that were equal among those who are moral, was to be rational beings with their purpose and capability to recognise a sense of justice. The similarity between the position of the indigenous peoples as a unitary state and as individuals within the society who choose pada gelahang marriages to fulfil the right of equality.

From the standpoint of morality, ethics and religion, the state (local government) in the form of legislative, is to be able to integrate the ways to appreciate the varying public opinion of those who choose pada gelahang marriages, based on the belief they have professed morally to apply transitional social equality (there are differential variations among the places). Any 
government policies concerning directly or indirectly with indigenous peoples must be communicated so that the policies may be received well with no grievances from any party.

Complementarity between customary laws (local wisdom) and state laws in the implementation of pada gelahang marriage can be termed as a symbiosis implementation of pada gelahang marriage. In another sense, the rules behind these two different types of laws which are mutually interacting, mutually complementary, and mutually reinforcing ideals that then regulate the implementation of pada gelahang marriages.

This was necessary to avoid cultural and political conflicts, as a result of tug of war between the interests of the state (government) through its legal instruments and the interests of the indigenous villages with their traditional laws, kala, patra, desa mawacara (Astara, 2010). The chart in figure 1 illustrates the implementation arrangement of pada gelahang marriage based on local wisdom and Pancasila.

\section{Caption:}

1. Number 33 symbolizes moral, ethical, and religious values, related to the regulation of the implementation of marriage in the wild, moral values, ethics and religion represented by the teachings of Hinduism. Number 22 symbolizes State law, and legal positivism, related to regulating the implementation of marriage in a chaotic manner, State legal norms are represented by the Marriage Law, while number 11 represents

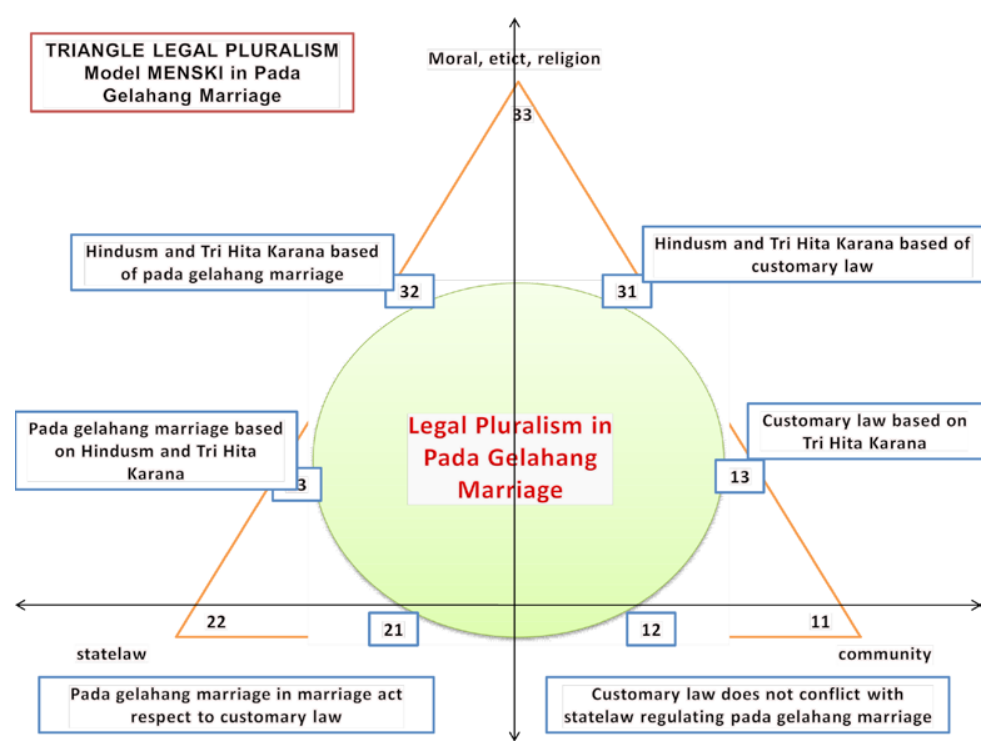

Figure 1. Legal pluralism model in pada gelahang marriage 
the law of society, in relation to regulating the implementation of marriage in gelahang represented by adat law or awig-awig customary village each. Based on the pluralism triangle image Menski above there are numbers that symbolize the slices between the three norms, while the slices represent the attraction relationship which should lead to a co-existence relationship.

2. Number 31 means that the teachings of Hindu law regarding marriage, regulation and implementation must not be released from the conditions in the community, and still respect the existence of existing legal communities that also regulate the implementation of a marriage in the wild. Number 32 means that the teachings of Hinduism in the regulation and implementation must not be released from the State law in this case the Basic Marriage Law.

3. Number 12 means that the customary law governing community on the implementation of pada gelahang marriage, in particular to its substance, must be respected and its presence must be recognized by regional regulation both at provincial and district/municipal level. Number 13 means that the customary laws of the indigenous village community that regulates the implementation of the marriage must abide by the spirit of the values according to the Hindu doctrine governing the implementation arrangements of pada gelahang marriage.

4. Number 21 means that the rule containing the implementation arrangements of pada gelahang marriage therein should also recognize and respect the values of customary law or legal entity of the indigenous people from the indigenous village, not only in the form of acknowledgement, but its existence can run alongside local law and with the law of the state.

5. Number 22 means that the regulations that contain the implementation of pada gelahang marriages strengthen the religious norms.

\section{Closing}

\section{Conclusion}

1. Based on the discussion of various issues in this article, several conclusions can be conveyed, including pada gelahang marriages are in accordance with Hindu law and strengthened by Balinese customary law. Pada gelahang marriages do not conflict with Hindu laws because of its underlying foundations, including: 1) philosophical foundation, which consists of a) the desire to be able to carry out obligations (swadharma) and rights (swadikara) as a child in Bali equally, b) Reach "Moksartham Jagadhita ya ca iti Dharma", birth happiness and inner (moksa), c) 
pada gelahang marriage has a national philosophical foundation in the Pancasila. There is a balance between rights and obligations, and the existence of mutual agreement based on the values of justice obtained from a democratic approach and consensus, d) Running Catur Sasana, namely Dewa Sasana, Pitra Sasana, Putra Sasana, and Susila Sasana, and e) Philosophically, pada gelahang marriage is legal according to Hindu law, 2) Juridical foundation, which consists of : a) pada gelahang marriage of the spirit is in a mutual agreement, the legal foundation certainly cannot be separated from the principle of action, which means that the agreement or agreement becomes the law of the two parties who made the agreement contained in Article 1338 of the Civil Code, b) pada gelahang marriage is based on national law contained in Law No. 1 (1974) concerning Marriage Principles and Government Regulation No. 9 (1975) concerning the Implementation of the Principles of Marriage, c) Decision of Cassation of the Supreme Court of the Republic of Indonesia No. $1331 \mathrm{~K} / \mathrm{Pdt} 12010$ examines civil matters in the cassation level, d) pada gelahang marriage has been recognized through the Conclusions in meeting PHDI Bali Province dated December 29, 2008 contains several conclusions recommended by the PHDI Prop. Bali with the PHDI Grand Passion Decree Number 13/Kep/P.A.Parisada/X/2009, e) by customary law, gated marriage in each customary village is in accordance with the respective awig-awig rules about pada gelahang marriage. f) Decision of the Pakraman Bali Village Main Assembly (MUDP) Bali Number 01/Kep/PSM-3/MDP Bali/X/2010 dated October 15, 2010 regarding the Results of the Third Great Companion of the Main Assembly of Pakraman Village, Bali. One decision points to the development of pada gelahang marriages made in the frivolous because of the inability on the part of the bride and groom and their family that cannot choose the traditional form of marriage in Bali, due to the fact that they are the only child of the family and expected to be the successor, 3) Within the sociological aspect, the number of pada gelahang couples in 2012 showed an even distribution of 49 such marriages in each regency or city in Bali.

2. Complementing each other, customary law (local wisdom) and state law in the implementation of pada gelahang marriage can be termed as a symbiosis of the implementation of a pada gelahang marriage. In another sense, the law is built by two different types of laws which then interact with each 
other to complement each other to become an ideal force in regulating the implementation of a pada gelahang marriage. This is necessary to avoid the occurrence of political battles between state law and cultural politics, due to the occurrence of attraction between the interests of the state (regional government) through its legal instruments with traditional villages that have the character of village law, kala, patra, Desa mawacara.

\section{Recommendations}

The advice can be delivered related to the study of pada gelahang marriage perspective on the law of Hinduism, among others: To the Provincial Government of Bali to form a study team that examines the SWOT analysis of pada gelahang marriages in Bali and to the Institute of Hindus, namely Parisadha Hindu Dharma Indonesia Central and Main Assembly Pakraman in Bali to keep conducting research and socialization on pada gelahang marriages in Bali. In addition, colleges in Bali based on religion and culture could also be advised to take part in the pada gelahang marriages.[]

\section{References}

Arta Dipa, Kontroversi Perkawinan Pada Gelahang Pada Masyarakat Hindu Bali di Karangasem, 2018.

Astara, Wesna Pertarungan Politik Hukum negara dan Politik Kebudayaan, Otonomisasi Desa Adat di Bali, Denpasar: Udayana University Press, 2010, pp.4.

Windia, Perkawinan Pada Gelahang di Bali, Denpasar: Bali Santhi, 2014, pp.7

Windia, Hukum Adat Bali dalam Tanya Jawab, Denpasar: Bali Santhi, 2013

Sudantra. Tri Semaya Hukum Adat Bali: Potret Perkembangan, 2011

Sukirno, Rekonstruksi Politik Hukum pengakuan Negara terhadap Hak Ulayat (Studi Pengakuan dan Perlindungan Eksistensi Hak Ulayat Masyarakat Hukum Adat Baduy dari Hegemoni Negara, Disertasi, Semarang: Program Doktor Ilmu Hukum, UNDIP Semarang, pp. 378, 2014. 